\title{
Transport and Recovery of Turbot (Scophthalmus maximus) Sedated with MS-222 and Eugenol: Effects on Intermediary Metabolism and Osmoregulation
}

\author{
Jie Cao ${ }^{1}$, Qi Wang ${ }^{1}$, Weiqiang Qiu ${ }^{1,2,3,4}$, Jun Mei ${ }^{1,2,3,4, *(1)}$ and Jing Xie ${ }^{1,2,3,4, * \text { (I) }}$ \\ 1 College of Food Science and Technology, Shanghai Ocean University, Shanghai 201306, China; \\ m190300743@st.shou.edu.cn (J.C.); m190310920@st.shou.edu.cn (Q.W.); wqqiu@shou.edu.cn (W.Q.) \\ 2 National Experimental Teaching Demonstration Center for Food Science and Engineering, Shanghai Ocean \\ University, Shanghai 201306, China \\ 3 Shanghai Engineering Research Center of Aquatic Product Processing and Preservation, \\ Shanghai 201306, China \\ 4 Shanghai Professional Technology Service Platform on Cold Chain Equipment Performance and Energy \\ Saving Evaluation, Shanghai 201306, China \\ * Correspondence: jmei@shou.edu.cn (J.M.); jxie@shou.edu.cn (J.X.); Tel.: +86-21-6190-0349 (J.M.); \\ +86-21-6190-0351 (J.X.)
}

check for updates

Citation: Cao, J.; Wang, Q.; Qiu, W.; Mei, J.; Xie, J. Transport and Recovery of Turbot (Scophthalmus maximus) Sedated with MS-222 and Eugenol: Effects on Intermediary Metabolism and Osmoregulation. Animals 2021, 11, 2228. https://doi.org/10.3390/ ani11082228

Academic Editor:

Luis Vargas-Chacoff

Received: 22 June 2021

Accepted: 27 July 2021

Published: 29 July 2021

Publisher's Note: MDPI stays neutral with regard to jurisdictional claims in published maps and institutional affiliations.

Copyright: (c) 2021 by the authors. Licensee MDPI, Basel, Switzerland. This article is an open access article distributed under the terms and conditions of the Creative Commons Attribution (CC BY) license (https:// creativecommons.org/licenses/by/ $4.0 /)$.
Simple Summary: The waterless transportation of live fish is considered to be a green and economic solution to achieve a high survival rate. However, the effects of cold domestication and the environment after leaving the water are prone to cause stress in fish. In this experiment, the turbots were anesthetized with $40 \mathrm{mg} / \mathrm{L} \mathrm{MS}-222$ and $20 \mathrm{mg} / \mathrm{L}$ eugenol solution. Then, turbots were cooled to dormancy, followed by waterless transport for $18 \mathrm{~h}$. The results of blood physiological indices indicated that the MS-222 and eugenol could reduce the stress on turbot during cooling and simulated waterless transport.

Abstract: This study focused on the anesthetic waterless keep-alive transport technique for turbot. MS-222 and eugenol were used to anesthetize turbot and then the waterless keep-alive transport was conducted. The blood physiological changes and flesh quality changes of turbot were evaluated after cooling and during the simulated waterless transport. The results show that the temperature lowered from 13 to $2{ }^{\circ} \mathrm{C}$, resulting in a decrease in moisture, fat and protein contents of all samples. Compared to the control turbot, the turbots treated with MS-222 and eugenol presented higher $\mathrm{pH}$ and glycogen content. During the simulated waterless transport, the $\mathrm{pH}$, ATP and glycogen contents in MS-222- and eugenol-treated turbots decreased and the IMP and lactate levels increased. For the blood biochemical indices, blood glucose, cortisol and urea nitrogen increased with the increase in transport time in MS-222- and eugenol-treated turbots. At sampling time, the changes in blood physiological indices were significantly higher in the control samples than those in the MS-222- and eugenol-treated samples. The results indicate that the turbot samples treated with MS-222 or eugenol could reduce stress during cooling and simulated waterless transport.

Keywords: anesthesia; turbot; waterless transport; physiological indicators; biochemical indicators

\section{Introduction}

Turbot (Scophthalmus maximus) is one of the most important economic fish in China and its output in 2019 exceeded 116,000 tons (China Fishery Statistical Yearbook, 2020). Most turbots are sold in the domestic market as fresh chilled products rather than as live fish. However, traditional live-water transportation techniques for turbot are usually accompanied by high costs and high rates of loss over long distances, thus significantly limiting the development of the live fish market industry [1]. It is important to explore new 
transportation techniques to improve the transportation of live turbot by reducing costs, increasing survival rates and extending transit times.

Waterless transportation of live fish is considered as a green and economical solution to achieve high survival rates and quantity $[2,3]$. Several studies have shown that waterless transport methods have been applied to the live transport of some cold-water fish species, such as sturgeon farmed in China and rainbow trout fingerlings [2]. The key to successful transportation of waterless fish is the cold-induced dormancy. However, cold acclimation could cause oxidative stress, affect the immune system and even cause tissue damage, which reduces the viability of acclimated fish [4]. The use of slow physical cooling and anesthetic treatment could reduce the oxidative stress of the fish in the early stage of keep-alive transportation and the stress response after leaving the water environment, avoiding the fish's struggle, reducing the level of metabolism and prolonging the waterless transportation time.

Fish anesthetics have been widely used in water transportation of live fish. MS-222 and eugenol are the most widely used. Eugenol (4-butallyl-2-methoxyphenol) is the main component of clove oil. It has the advantages of good practicability and low price, so it has been widely used. Existing studies show that eugenol has been applied in the anesthetic transportation of freshwater angelfish, juvenile (Lophiosilurus alexandri) and Nile tilapia [5-7]. Tricaine methane-sulfonate, or MS-222, it is an inhalation anesthetic, usually used in fish [8]. MS-222 has low drug concentration, fast anesthesia, fast recovery and no toxic side effects. It is currently the only anesthetic used by the Food and Drug Administration (USFDA) for food fish [9]. At present, MS-222 has been used in the anesthesia and transportation research of Largemouth Bass, pikeperch (Sander lucioperca), lumpfish (Cyclopterus lumpus) and Far Eastern Catfish (Silurus asotus), and so on [10-13]. Feng G et al. and Palić D et al. also studied the effects of MS-222 and eugenol on blood biochemical parameters of juvenile Siberian sturgeon (Acipenser baerii) and on the cellular function of fathead minnows (Pimephales promelas) [14,15]. In addition, Teles M et al. studied the effect of eugenol and MS-222 on the oxidative stress state of gilthead sea bream (Sparus aurata L.) during anesthetized transport and after recovery [16]. In this experiment, eugenol and MS-222 were used to anesthetize turbot, and then proceed to waterless transportation. The purpose of this study was to provide a theoretical basis for the application of waterless transport methods for turbot to help keep the fish alive and maintain its vitality and quality.

\section{Materials and Methods}

\subsection{Preparation of Turbot}

The experimental protocol was approved by the Institutional Animal Care and Use Committee of Shanghai Ocean University (SHOU-DW-2021-066). A total of 100 live cultured turbot (weight $600 \pm 50 \mathrm{~g}$ ) were purchased from the local market in Luchao port town (Shanghai, China) and then transported to the laboratory in a truck equipped with holding tanks. The fish were kept in prepared polyethylene-based tanks $\left(2.4 \times 1.7 \times 0.6 \mathrm{~m}^{3}\right)$ for 2 days prior to the experiment to acclimatize to the experimental environment. The average water temperature was $13^{\circ} \mathrm{C}$, the salinity of seawater was $30 \%$, the average $\mathrm{pH}$ was 7.5 and the average dissolved oxygen was $6.0 \mathrm{mg} \cdot \mathrm{L}^{-1}$.

MS-222 and the corresponding weight of sodium bicarbonate were dissolved in seawater at concentrations of $40 \mathrm{mg} / \mathrm{L}$. Considering the hydrophobicity of eugenol, the anesthetic solution was prepared by dilution in $95 \%$ ethanol at a ratio of 1:9 to make a stock solution (100 g/L) for later use [17]. Then, the eugenol solution was dissolved in seawater to prepare $20 \mathrm{mg} / \mathrm{L}$ eugenol solution. These concentrations were determined in pre-tests.

The turbot was divided into 3 groups: (a) M-222 treatment: 30 healthy turbots treated with $40 \mathrm{mg} / \mathrm{L}$ MS-222 solution; (b) Eugenol treatment: 30 healthy turbots treated with 20 $\mathrm{mg} / \mathrm{L}$ eugenol solution; and (c) Control treatment: the turbot was transported without anesthesia treatment. After turbots were anesthetized, the water temperature dropped from 13 to $2{ }^{\circ} \mathrm{C}$ at a rate of $1{ }^{\circ} \mathrm{C}$ per hour. After cooling to $2{ }^{\circ} \mathrm{C}$, the fish were confirmed to be in a dormant state and their fins and gills were observed to be almost immobile [4]. The 
dormant turbots were gently put into a plastic bag that was then filled with oxygen. Then, the turbots were put into an insulated box and the waterless transport was simulated in a vibration conveyor under $100 \mathrm{rpm}$ at $2{ }^{\circ} \mathrm{C}$ for $18 \mathrm{~h}$.

\subsection{Measurements and Analytical Procedures}

\subsubsection{Sample Collection}

Three turbot samples were randomly selected from each group and analyzed at 0 , 6,12 and $18 \mathrm{~h}$ during simulated waterless transport and after $48 \mathrm{~h}$ of recovery in water, respectively. A $2 \mathrm{~mL}$ disposable syringe was used to draw blood from the tail vein without adding anticoagulant. Blood was transferred to $2.0 \mathrm{~mL}$ centrifuge tubes and let stand in a refrigerator at $4{ }^{\circ} \mathrm{C}$ for $2 \mathrm{~h}$. Then, it was centrifuged at $3000 \mathrm{rpm}$ for $15 \mathrm{~min}$. The serum was collected in a $1.5 \mathrm{~mL}$ centrifuge tube and stored at $-20^{\circ} \mathrm{C}$ until analysis [18]. Flesh tissues from the back and abdomen of each fish were collected for biochemical analysis.

\subsubsection{Chemical Composition of Flesh}

In the experiment, the water, crude fat and crude protein contents of turbot muscle were determined by determined according to the national standard method [19].

\subsubsection{Flesh $\mathrm{pH}$}

A pH probe (Testo 205, Detu Instruments International Trade Co., Shanghai, China) was inserted to measure flesh $\mathrm{pH}$ after slaughter. The flesh $\mathrm{pH}$ was measured at three different parts of the fish body; the upper part of the fish fillet, the back part of the back flesh and the abdominal flesh. The flesh $\mathrm{pH}$ was calculated as the average of three measurements.

\subsubsection{Biochemical Analysis of Flesh Samples}

Determination of lactic acid and glycogen in turbot flesh was achieved by measuring with lactic acid and glycogen (Nanjing Jiancheng Institute of Bioengineering, Nanjing, China) and reading with a UV-2100 UV-Visible Spectrophotometer (Unico Instruments Co., Ltd., Franksville, WI, USA).

\subsubsection{Determination of Nucleotides}

Nucleotide extracts were prepared according to the method of Fang et al. [20]. ATPrelated compounds, including adenosine triphosphate (ATP), inosine monophosphate (IMP) and adenosine monophosphate (AMP), were analyzed while using HPLC (Waters 2695, Milford, CT, USA), equipped with a VP-CDS C18 column $(150 \times 46 \mathrm{~mm})$.

\subsubsection{Determination of Serum Biochemical Indicators}

The biochemical indices of serum, including glucose (GLU) and blood urea nitrogen (BUN), were determined by using commercial assay kits (Nanjing Jiancheng Institute of Bioengineering, Nanjing, China) according to the manufacturer's instructions. Serum cortisol was determined by means of an enzyme-linked immunoassay according to the Cortisol ELISA Kit manufacturer's instructions (Shanghai Fanke Industrial Co., Ltd., Shanghai, China).

\subsubsection{Statistical Analysis}

Data were expressed as the mean $\pm \mathrm{SD}$ and the one-way analysis of variance (ANOVA) procedure (International Business Machines Corporation, Armonk, NY, USA) followed by Duncan's multiple range tests was adopted to determine the significant difference $(p<0.05)$ between treatments.

\section{Results}

\subsection{Chemical Composition of Flesh}

As shown in Table 1, the moisture and protein contents of turbot in each treatment group were significantly reduced when the temperature was lowered from 13 to $2{ }^{\circ} \mathrm{C}$ 
dormant temperature $(p<0.05)$, in which the water and protein content of turbot in the control group decreased by $0.78 \%$ and $0.57 \%$, while the water and protein content of turbot in the MS-222-treated group decreased by $0.45 \%$ and $0.42 \%$, and the water and protein content of turbot in the eugenol-treated group decreased by $0.47 \%$ and $0.40 \%$. After $18 \mathrm{~h}$ of simulated transport, the moisture, fat and protein contents of turbot flesh in each treatment group decreased significantly $(p<0.05)$ compared with the turbot flesh at $0 \mathrm{~h}$. Among them, the moisture and protein contents of turbot flesh in the CK sample decreased by $0.60 \%$ and $0.46 \%$ at the end of simulated transport, while the moisture and protein content of turbot in the MS-222-treated group decreased by $0.57 \%$ and $0.42 \%$, and the moisture and protein content of turbot in the eugenol-treated group decreased by $0.47 \%$ and $0.34 \%$. The results show that low-temperature stress also had as great effect as that of transport stress on flesh quality. The moisture, fat and protein contents of turbot in each treatment group were restored to their initial levels after $48 \mathrm{~h}$ of resuscitation.

Table 1. The effect of low-temperature waterless transport stress on the chemical composition of turbot flesh.

\begin{tabular}{|c|c|c|c|c|c|c|c|}
\hline Indicators/Transport & Samples & $13^{\circ} \mathrm{C}$ & $2^{\circ} \mathrm{C}-0 \mathrm{~h}$ & $2^{\circ} \mathrm{C}-6 \mathrm{~h}$ & $2{ }^{\circ} \mathrm{C}-12 \mathrm{~h}$ & $12{ }^{\circ} \mathrm{C}-18 \mathrm{~h}$ & Recovery-48 h \\
\hline \multirow{3}{*}{ Water content $(\%)$} & Control & $78.89 \pm 0.26^{\mathrm{Aa}}$ & $78.11 \pm 0.10^{\mathrm{Ab}}$ & $77.87 \pm 0.11^{\mathrm{Ac}}$ & $77.63 \pm 0.06 \mathrm{Ad}$ & $77.51 \pm 0.08 \mathrm{Ad}$ & $78.80 \pm 0.12^{\mathrm{Aa}}$ \\
\hline & MS-222 & $78.77 \pm 0.19 \mathrm{Aa}$ & $78.32 \pm 0.08^{\mathrm{Bb}}$ & $78.11 \pm 0.12^{\mathrm{ABC}}$ & $77.93 \pm 0.13^{\mathrm{Bd}}$ & $77.75 \pm 0.05^{\mathrm{Bd}}$ & $78.67 \pm 0.09 \mathrm{Aa}$ \\
\hline & Eugenol & $78.74 \pm 0.33^{\mathrm{Aa}}$ & $78.27 \pm 0.11 \mathrm{ABb}$ & $78.10 \pm 0.05^{\mathrm{Bc}}$ & $77.95 \pm 0.07^{\mathrm{Bd}}$ & $77.80 \pm 0.10^{\mathrm{Bd}}$ & $78.66 \pm 0.15^{\mathrm{Aa}}$ \\
\hline \multirow{3}{*}{ Crude fat $(\%)$} & Control & $1.44 \pm 0.06^{\mathrm{Aa}}$ & $1.24 \pm 0.04^{\mathrm{Ab}}$ & $1.17 \pm 0.03^{\mathrm{Abc}}$ & $1.10 \pm 0.04^{\mathrm{Acd}}$ & $1.04 \pm 0.05^{\mathrm{Ad}}$ & $1.39 \pm 0.08^{\mathrm{Aa}}$ \\
\hline & MS-222 & $1.47 \pm 0.05^{\mathrm{Aa}}$ & $1.32 \pm 0.07^{\mathrm{Bb}}$ & $1.24 \pm 0.05 \mathrm{Abc}$ & $1.16 \pm 0.03$ Acd & $1.10 \pm 0.06^{\mathrm{Ad}}$ & $1.41 \pm 0.07^{\mathrm{Aa}}$ \\
\hline & Eugenol & $1.40 \pm 0.03^{\mathrm{Aa}}$ & $1.28 \pm 0.05 \mathrm{ABb}$ & $1.22 \pm 0.04^{\mathrm{Ab}}$ & $1.18 \pm 0.05^{\mathrm{Abc}}$ & $1.12 \pm 0.05^{\mathrm{Ac}}$ & $1.37 \pm 0.06^{\mathrm{Aa}}$ \\
\hline \multirow{3}{*}{ Crude protein $(\%)$} & Control & $18.65 \pm 0.11^{\mathrm{Aa}}$ & $18.08 \pm 0.10 \mathrm{Ab}$ & $17.95 \pm 0.05 \mathrm{Ab}$ & $17.83 \pm 0.16^{\mathrm{Abc}}$ & $17.62 \pm 0.10^{\mathrm{Ac}}$ & $18.51 \pm 0.09 \mathrm{Aa}$ \\
\hline & MS-222 & $18.61 \pm 0.07^{\mathrm{Aa}}$ & $18.19 \pm 0.09 \mathrm{ABb}$ & $18.06 \pm 0.14 \mathrm{ABb}$ & $17.98 \pm 0.11^{\mathrm{Ab}}$ & $17.89 \pm 0.14 \mathrm{ABb}$ & $18.60 \pm 0.11$ Аa \\
\hline & Eugenol & $18.66 \pm 0.09$ Аa & $18.26 \pm 0.0 .05^{\mathrm{Bb}}$ & $18.13 \pm 0.08^{\mathrm{Bb}}$ & $18.00 \pm 0.10^{\mathrm{Abc}}$ & $17.92 \pm 0.07^{\mathrm{Bc}}$ & $18.69 \pm 0.13^{\mathrm{Aa}}$ \\
\hline
\end{tabular}

Different capital letters indicate significant differences in means between different treatment groups. Different lowercase letters indicate significant differences in means between the same treatment groups $(p<0.05)$.

\subsection{Flesh Biochemical Indicators}

The changes in lactic acid, glycogen contents and $\mathrm{pH}$ value of turbot during lowtemperature waterless transport are shown in Figure 1. The flesh glycogen contents of turbot in all samples decreased significantly $(p<0.05)$ when the water temperature decreased from 13 to $2{ }^{\circ} \mathrm{C}$. Additionally, the $\mathrm{pH}$ and glycogen content of turbot in the MS222- and eugenol-treated groups were significantly higher than those in the control group. After $18 \mathrm{~h}$ of simulated transport, the turbots in control group showed a $21 \%$ increase in lactic acid content and a 17\% decrease in glycogen content; the turbots in the MS-222 treated group showed a 13\% increase in lactic acid content and a 12\% decrease in glycogen content, and the turbots in the eugenol-treated turbot group showed a $12 \%$ increase in lactic acid content and a $14 \%$ decrease in glycogen content. After the simulated transport, the flesh pH of turbot decreased from 6.82 to 6.42 in the control group, from 6.86 to 6.52 in the MS-222-treated group and from 6.84 to 6.56 in the eugenol-treated group. The lactic acid, glycogen contents and $\mathrm{pH}$ value of all turbot samples returned to the initial level after $48 \mathrm{~h}$ of resuscitation.

\subsection{Changes in Blood Glucose and Flesh ATP in Turbot during Simulated Transport}

The flesh ATP content of turbot remained at a high level after cooling and at $0 \mathrm{~h}$ of transport. There was no significant change in the flesh ATP content of turbot in each treatment group after the end of cold domestication. The results show that the ATP contents in turbot flesh were significantly lower at the end of transport compared with those at $0 \mathrm{~h}$. The flesh ATP content of turbot in the control group was significantly lower than that of turbot in the MS-222- and eugenol-treated groups $(p<0.05)$. Glucose levels in turbot blood increased with transport time and the CK sample had a more pronounced increase (Figure 2B). At each sampling time point, glucose levels were significantly higher in control turbot than in fish from the MS-222 and eugenol treatment groups $(p<0.05)$. 

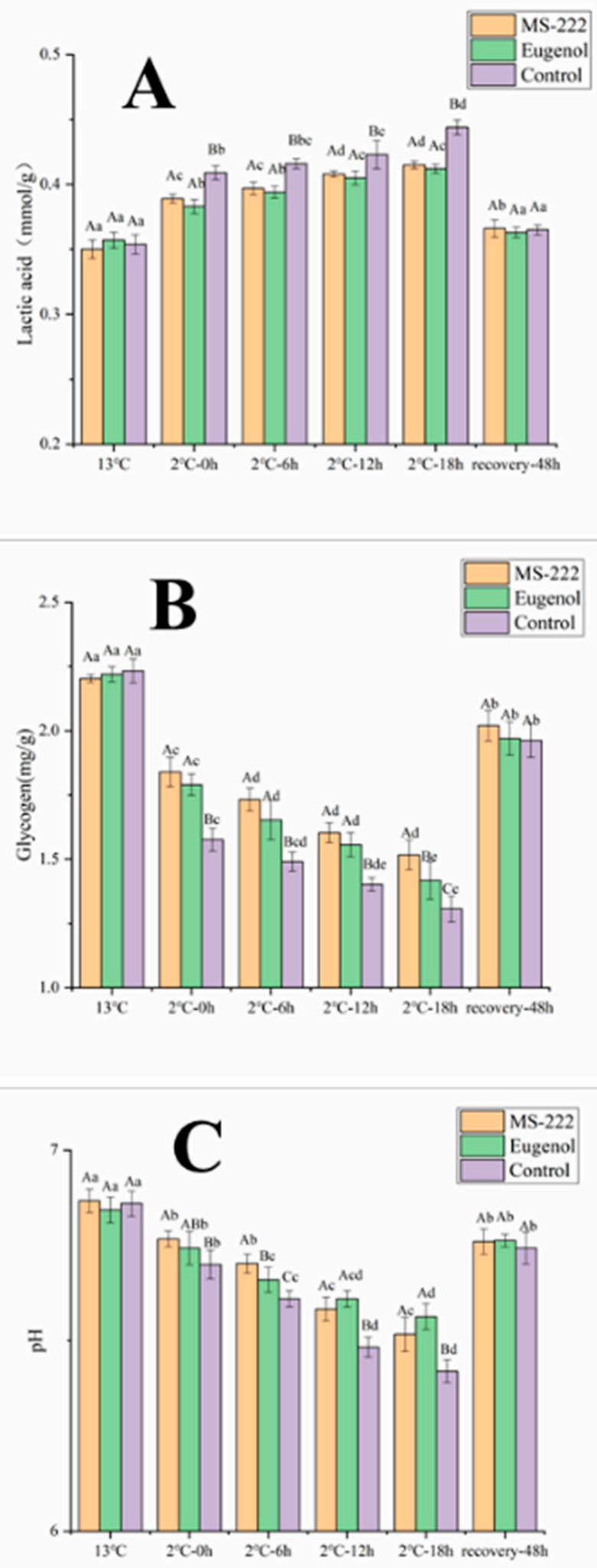

Figure 1. Flesh glycogen (A), lactic acid (B) and $\mathrm{pH}(\mathbf{C})$ changes of turbot affected by low temperature transport stress. Different capital letters indicate significant differences in means between different treatment groups. Different lowercase letters indicate significant differences in means between the same treatment groups $(p<0.05)$. 

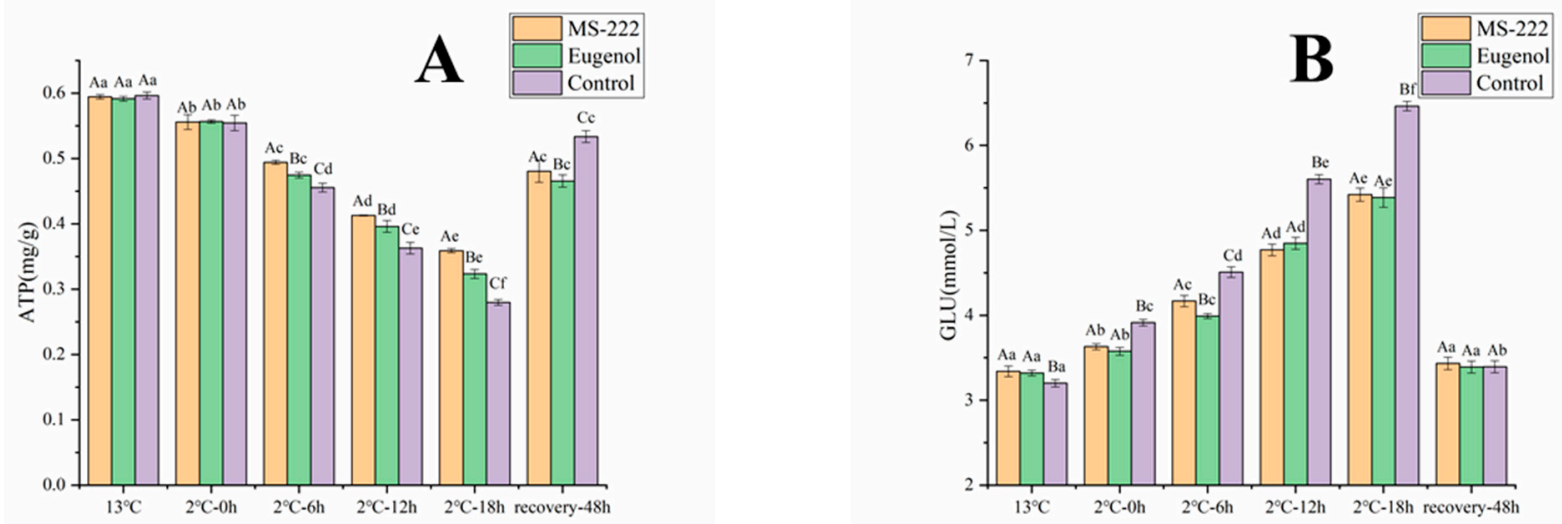

Figure 2. ATP (A) and blood glucose (B) changes in turbot affected by low-temperature transport stress. Different capital letters indicate significant differences in means between different treatment groups. Different lowercase letters indicate significant differences in means between the same treatment groups $(p<0.05)$.

\subsection{Changes of Cortisol and BUN in Turbot during Waterless Transport}

Serum cortisol levels were significantly elevated at the end of transport in all turbot treatment groups, with a 50\% increase in the control group, a 32\% increase in the MS-222treated group and a 30\% increase in the eugenol-treated group. Cortisol levels gradually returned to initial levels after $48 \mathrm{~h}$ of resuscitation (Figure 3). These results suggest that MS-222 and eugenol preanesthetic treatments were able to inhibit the increase in blood cortisol levels compared with the control group.
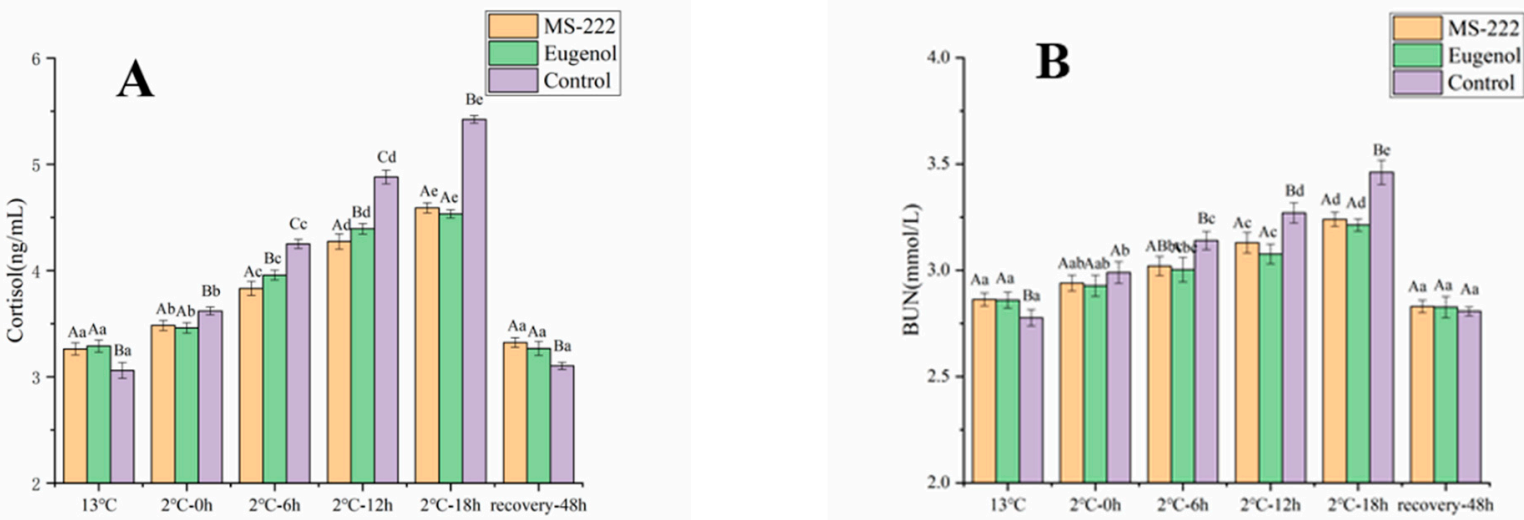

Figure 3. Cortisol (A) and BUN (B) changes in turbot affected by low-temperature transport stress. Different capital letters indicate significant differences in means between different treatment groups. Different lowercase letters indicate significant differences in means between the same treatment groups $(p<0.05)$.

Blood urea nitrogen concentrations changed slowly in the MS-222- and eugenoltreated turbot samples compared with the CK samples during the simulated transport. In contrast, blood urea nitrogen concentrations increased significantly in the control group, increasing to 3.27 and $3.46 \mathrm{mmol} / \mathrm{L}$ at the 12th and 18th $\mathrm{h}$, respectively. Blood urea nitrogen levels returned to the initial levels in all samples after $48 \mathrm{~h}$ of resuscitation.

\subsection{Changes of Nucleotides in Turbot}

The changes in flesh flavor nucleotide content of turbot during waterless transport are shown in Table 2. The IMP value gradually increased and the AMP value decreased during simulated transport. At the end of transport, the increase in IMP of turbot flesh in the control group was $28.47 \%$ and TAV increased to 14.79 ; the increase in IMP of turbot flesh in the MS-222-treated group was $18.06 \%$ and TAV increased to 13.99; and the increase in IMP of turbot flesh in the eugenol-treated group was $12.44 \%$ and TAV increased to 13.96 . 
However, the AMP values decreased from hour to hour and then increased to the end of transport. The flesh AMP in CK, MS-222- and eugenol-treated samples decreased by $14.72 \%, 0.6 \%$ and $4.2 \%$, respectively.

Table 2. Changes in nucleotides of turbot during waterless transport.

\begin{tabular}{|c|c|c|c|c|c|}
\hline Transport (h) & Sample & IMP (mg/100 g) & TAV & AMP (mg/100 g) & TAV \\
\hline \multirow{3}{*}{$13^{\circ} \mathrm{C}$} & Control & $319.44 \pm 11.55^{\mathrm{Ab}}$ & 12.78 & $24.73 \pm 0.71 \mathrm{Aa}$ & 0.49 \\
\hline & MS-222 & $312.45 \pm 6.11^{\mathrm{Ab}}$ & 12.50 & $20.96 \pm 0.76^{\mathrm{Ba}}$ & 0.42 \\
\hline & Eugenol & $310.37 \pm 5.20^{\mathrm{Ab}}$ & 12.41 & $21.62 \pm 1.09 \mathrm{Ba}$ & 0.43 \\
\hline \multirow{3}{*}{$2{ }^{\circ} \mathrm{C}-0 \mathrm{~h}$} & Control & $287.81 \pm 7.29$ Аа & 11.51 & $19.41 \pm 1.14^{\mathrm{Ab}}$ & 0.39 \\
\hline & MS-222 & $296.17 \pm 5.16^{\mathrm{Aa}}$ & 11.85 & $18.23 \pm 0.97 \mathrm{Ab}$ & 0.36 \\
\hline & Eugenol & $292.50 \pm 5.65$ Аа & 11.70 & $18.96 \pm 1.63 \mathrm{Abc}$ & 0.38 \\
\hline \multirow{3}{*}{$2^{\circ} \mathrm{C}-6 \mathrm{~h}$} & Control & $343.39 \pm 7.86^{\mathrm{Ac}}$ & 13.74 & $16.65 \pm 0.80 \mathrm{Ac}$ & 0.33 \\
\hline & MS-222 & $325.91 \pm 5.25 \mathrm{Bc}$ & 13.04 & $15.99 \pm 0.63^{\mathrm{Ac}}$ & 0.32 \\
\hline & Eugenol & $325.63 \pm 3.31^{\mathrm{Bc}}$ & 13.03 & $16.74 \pm 1.41$ Acd & 0.33 \\
\hline \multirow{3}{*}{$2^{\circ} \mathrm{C}-12 \mathrm{~h}$} & Control & $356.18 \pm 6.04 \mathrm{Acd}$ & 14.25 & $13.81 \pm 0.47^{\mathrm{Bd}}$ & 0.28 \\
\hline & MS-222 & $340.62 \pm 2.36^{\mathrm{Bd}}$ & 13.62 & $14.55 \pm 0.48^{\mathrm{ABc}}$ & 0.29 \\
\hline & Eugenol & $341.49 \pm 5.69^{\mathrm{Bd}}$ & 13.66 & $15.41 \pm 1.21 \mathrm{Ad}$ & 0.31 \\
\hline \multirow{3}{*}{$2^{\circ} \mathrm{C}-18 \mathrm{~h}$} & Control & $369.76 \pm 7.22 \mathrm{Ad}$ & 14.79 & $16.92 \pm 1.39 \mathrm{Bc}$ & 0.34 \\
\hline & MS-222 & $349.67 \pm 1.44^{\mathrm{Be}}$ & 13.99 & $18.11 \pm 1.19^{\mathrm{Ab}}$ & 0.36 \\
\hline & Eugenol & $348.97 \pm 6.69 \mathrm{Bd}$ & 13.96 & $18.2 \pm 0.23 \mathrm{Abc}$ & 0.36 \\
\hline \multirow{3}{*}{ Recovery-48 h } & Control & $320.00 \pm 13.62^{\mathrm{Ab}}$ & 12.80 & $23.24 \pm 0.56^{\mathrm{Ba}}$ & 0.46 \\
\hline & MS-222 & $322.78 \pm 3.80 \mathrm{Ac}$ & 12.91 & $20.64 \pm 0.83 \mathrm{Aa}$ & 0.41 \\
\hline & Eugenol & $314.93 \pm 4.14^{\mathrm{Ab}}$ & 12.60 & $20.91 \pm 1.87$ Aab & 0.42 \\
\hline
\end{tabular}

Different capital letters indicate significant differences in means between different treatment groups. Different lowercase letters indicate significant differences in means between the same treatment groups $(p<0.05)$. TAV: Taste activity value. (IMP: $25 \mathrm{mg} / 100 \mathrm{~g}$, AMP: $50 \mathrm{mg} / 100 \mathrm{~g}$ ). IMP: inosine monophosphate. AMP: Adenosine monophosphate.

\section{Discussion}

Changes in temperature and transportation put tremendous pressure on fish [21], which led to the changes in the chemical composition of turbot flesh. The turbot secretes mucus to protect themselves during the waterless transportation, resulting in water loss. Mohamed et al. suggested that the reduction in the moisture content of fish after transport could be the result of metabolic disorders and abnormal enzyme functions [2]. Jrpeland et al. found that the water content of stressed Gadus morhua L. was significantly lower compared to unstressed fish [22].

During the waterless transportation of turbot, the content of protein and fat decreased significantly. It is speculated that the reasons for the decrease in the content of energysupplying substances such as protein and fat in the fish are on the one hand, because the fish is in a waterless low-temperature state during transportation, in order to provide nutrients to the organism and keep it alive, some of the nutrients in the fish meat were degraded, resulting in the denaturation of flesh protein [23]. On the other hand, the unfavorable environmental factors, such as vibration during transportation, continue to stimulate the fish body and consume energy, thereby promoting the decomposition of energy supply material. In this experiment, it was observed that there was no significant difference in flesh qualitative parameters between the anesthetized group turbot and the control group turbot flesh qualitative parameters. After $48 \mathrm{~h}$ of resuscitation, the basic nutrients of the fish's flesh could be restored to the level of the control group, and the consumption of the fish weight by simulated waterless transportation was negligible.

From the current research, under the stress of low temperature and transport, turbots maintain the energy requirements of the organism by catabolizing flesh glycogen. This may be due to the energy requirements during transportation. Once under stressful conditions, flesh glycogen reserves are mobilized to provide energy [24]. The decrease in oxygen 
during transport leads to an increase in anaerobic metabolism and the conversion of glycogen to lactate. According to Moraes et al. [25], reduced oxygen level is a common source of stress in fish, leading to a large export of lactate into the plasma. The increased lactate content in fish suggests that fish are unable to maintain initial internal homeostasis. Flesh $\mathrm{pH}$ is an important meat quality parameter and the accumulation of lactic acid in the flesh during transport leads to a decrease in flesh $\mathrm{pH}$ [26], which is consistent with the results obtained in this study. The decrease in flesh $\mathrm{pH}$ will reduce the quality of the flesh, through means such as loss of water retention capacity, and change the texture of the flesh [23]. The rate of decrease in glycogen and the rate of increase in lactic acid in the flesh of turbot in MS-222- and eugenol-treated groups were smaller than those in the control group during waterless transportation, which was because the fish were anesthetized, the metabolic rate was reduced and less lactic acid was accumulated in the flesh tissue, so the decrease spokes of glycogen and $\mathrm{pH}$ in the anesthetized turbot flesh were lower than those in the control group.

Adenosine triphosphate (ATP) provides the energy required to maintain normal life activities. Changes in the levels of ATP and its metabolites can indicate changes in the carnal energy of fish [27]. When the ambient temperature decreases, the main adaptive change that occurs in the organism is an increase in blood glucose levels. During cold stress conditions or prolonged exposure to low temperatures, the body converts large amounts of glucose into ATP to provide energy [28]. In the present study, blood glucose levels increased with transport time, indicating that that under waterless conditions, the fish body needs to release more glucose to maintain normal metabolism as the amount of respirable oxygen decreases It was found that the muscle ATP content of turbot in MS-222- and eugenol-treated groups was significantly lower than that of turbot in the control group at the end of transport, while the blood glucose level was significantly lower than that of the control group. This result suggests that the anesthetics can reduce the energy metabolism of the fish during transport, which is also similar to the findings of Eduardo et al. [29].

Serum cortisol is one of the most important indicators of stress levels in fish [30]. Under cold and stressful conditions, serum cortisol levels in fish increase significantly [27]. In addition, blood urea nitrogen (BUN), which is formed in the liver and excreted through the kidneys and is an important indicator of kidney function [31], also increases. Under stressful conditions, increased levels of cortisol and urea nitrogen facilitate the regulation of osmotic pressure and the maintenance of vital characteristics in bony fish [32]. Barton et al. showed that transport causes stress and increases serum cortisol levels in live fish [33]. The conditions of the external environment will activate the HPI system in fish, leading to the production of large amounts of cortisol hormones to regulate the ion permeability of cells and maintain physiological homeostasis [34]. In this study, cortisol levels in MS-222-treated and eugenol-treated turbots were significantly lower than those in the control group after cooling and transport. This is similar to the results obtained by Jerez-Cepa et al., suggesting that anesthetics can reduce the effects of transport stress [16]. The result of the study shows that anesthetized preservation of transported turbot could reduce the increase in cortisol and contribute to the survival of the fish.

ATP and its related compounds have taste characteristics and are the main source of taste in fish. IMP and AMP were the two main taste nucleotides in turbot during simulated transport. The TAV values of IMP in turbot flesh were greater than 10, indicating that IMP was the main source of taste in turbot flesh at $2{ }^{\circ} \mathrm{C}-0 \mathrm{~h}$, the IMP content of turbot in each treatment group was significantly lower than that of fish in the $13{ }^{\circ} \mathrm{C}$ treatment group, which was a temporary effect of the cooling operation on taste presenting substances. With the extension of transport time, the breakdown of ATP in turbot flesh led to the accumulation of IMP, and the content of IMP increased significantly, which is the same as the results of $\mathrm{Wu}$ Bo et al., who found a significant increase in IMP content in grouper flesh at the end of transport [35]. With the extension of transportation time, the AMP content of turbot first decreased and then increased, and after $18 \mathrm{~h}$, AMP was still at a high level, indicating that the low-temperature anhydrous transportation operation could increase 
the fresh flavor-presenting substances of turbot and improve the flavor of fish flesh. It was observed in this experiment that the level of IMP in the flesh of turbot in the control group was significantly higher than that in the MS-222- and eugenol-treated groups during anhydrous transport, due to the fact that the anesthetic manipulation reduced the energy metabolism of the fish and slowed down the degradation of ATP in the flesh. Thus, the IMP in the flesh of turbot in the treated group showed higher levels.

\section{Conclusions}

The results of the study show that after the pre-treatment with MS-222 and eugenol anesthesia, the large amount of energy consumed in the cooling process could be avoided, the cost savings could be substantial and the convenience, speed and time saving further met the requirements of commercial transportation of turbot. Because turbot has the function of skin respiration, in this kind of fish waterless keep-alive transport makes full use of the function of skin respiration, in maintaining the environmental requirements of the fish needed to maintain a certain level of humidity and oxygen, to prevent fish tissue dehydration and hypoxia. In the process of waterless keep-alive transport, water, crude fat and protein content of fish flesh decreased, glycogen content decreased, lactic acid content increased and flesh $\mathrm{pH}$ value decreased; blood glucose, cortisol and urea nitrogen content in blood increased significantly in the process of waterless keep-alive transport.

Author Contributions: Conceptualization, J.C. and Q.W.; Data curation, J.C. and Q.W.; Formal analysis, J.C.; Funding acquisition, J.X.; Investigation, J.C. and Q.W.; Methodology, J.C. and J.M.; Project administration, J.M. and J.X.; Software, J.C., Q.W. and J.M.; Validation, J.X.; Writing-original draft, J.C.; Writing - review \& editing, Weiqiang Qiu and J.X. All authors have read and agreed to the published version of the manuscript.

Funding: This research was funded by Shanghai Agriculture Applied Technology Development Program, China (2019-02-08-00-10-F01143) and National Key R\&D Program of China (2019YFD0901601).

Institutional Review Board Statement: In the present study, all procedures were performed in accordance with the "Guidelines for Experimental Animals" of the Ministry of Science and Technology (Beijing, China) and were approved by the Institutional Animal Care and Use Committee of Shanghai Ocean University (SHOU-DW-2021-066).

Data Availability Statement: All data, models, and code generated or used during the study appear in the submitted article.

Conflicts of Interest: The authors declare no conflict of interest.

\section{References}

1. He, R.P.; Su, Y.P.; Wang, A.L.; Lei, B.; Cui, K.P. Survival and serum biochemical responses of spotted sea bass Lateolabrax maculatus during simulated waterless live transportation. Aquacult. Res. 2020, 51, 3495-3505. [CrossRef]

2. Refaey, M.M.; Tian, X.; Tang, R.; Li, D.P. Changes in physiological responses, muscular composition and flesh quality of channel catfish Ictalurus punctatus suffering from transport stress. Aquaculture 2017, 478, 9-15. [CrossRef]

3. Zhang, Y.J.; Zhang, X.S.; Nga, M.T.T.; Yu, H.R. Development and evaluation of key ambient factors online monitoring system in live Urechis unicinctus transportation strategies. Comput. Electron. Agric. 2018, 145, 43-52. [CrossRef]

4. Nie, X.B.; Lei, J.L.; Chen, S.X.; Zhang, Y.T.; Zhang, C.F.; Hong, W.S. Physiological, proteomic, and gene expression analysis of turbot (Scophthalmus maximus) in response to cold acclimation. Aquaculture 2018, 495, 281-287. [CrossRef]

5. De Oliveira, C.P.B.; Lemos, C.H.D.; Silva, A.F.E.; de Souza, S.A.; Albinati, A.C.L.; Lima, A.O.; Copatti, C.E. Use of eugenol for the anaesthesia and transportation of freshwater angelfish (Pterophyllum scalare). Aquaculture 2019, 513, 6. [CrossRef]

6. Favero, G.C.; Silva, W.D.E.; Boaventura, T.P.; Leme, F.D.P.; Luz, R.K. Eugenol or salt to mitigate stress during the transport of juvenile Lophiosilurus alexandri, a Neotropical carnivorous freshwater catfish. Aquaculture 2019, 512, 6. [CrossRef]

7. Ribeiro, P.A.P.; Miranda, K.C.; De Melo, D.C.; Luz, R.K. Efficiency of eugenol as anesthetic for the early life stages of Nile tilapia (Oreochromis niloticus). An. Acad. Bras. Cienc. 2015, 87, 529-535. [CrossRef] [PubMed]

8. Popovic, N.T.; Strunjak-Perovic, I.; Coz-Rakovac, R.; Barisic, J.; Jadan, M.; Berakovic, A.P.; Klobucar, R.S. Tricaine methanesulfonate (MS-222) application in fish anaesthesia. J. Appl. Ichthyol. 2012, 28, 553-564. [CrossRef]

9. Park, I.-S.; Gil, H.W.; Lee, T.H.; Nam, Y.K.; Lim, S.G.; Kim, D.S. Effects of Clove Oil and Lidocaine-HCl Anesthesia on Water Parameter during Simulated Transportation in the Marine Medaka, Oryzias dancena. Dev. Reprod. 2017, 21, 19-33. [CrossRef] 
10. Prystay, T.S.; Elvidge, C.K.; Twardek, W.M.; Logan, J.M.; Reid, C.H.; Clarke, S.H.; Foster, J.G.; Cooke, E.L.L.; Cooke, S.J. Comparison of the Behavioral Consequences and Recovery Patterns of Largemouth Bass Exposed to MS-222 or Electrosedation. Trans. Am. Fish. Soc. 2017, 146, 556-566. [CrossRef]

11. Rozynski, M.; Ziomek, E.; Demska-Zakes, K.; Zakes, Z. Impact of inducing general anaesthesia with MS-222 on haematological and biochemical parameters of pikeperch (Sander lucioperca). Aquacult. Res. 2019, 50, 2125-2132. [CrossRef]

12. Jacobsen, J.V.; Steen, K.; Nilssen, K.J. Anaesthetic efficacy of Aqui-S, Benzoak, and MS-222 on lumpfish (Cyclopterus lumpus) fries. Impact from temperature, salinity, and fasting. PLoS ONE 2019, 14, 12. [CrossRef]

13. Park, I.-S. The Anesthetic Effects of Clove Oil and MS-222 on Far Eastern Catfish, Silurus asotus. Dev. Reprod. 2019, 23, 183-191. [CrossRef]

14. Feng, G.; Zhuang, P.; Zhang, L.; Kynard, B.; Shi, X.; Duan, M.; Liu, J.; Huang, X. Effect of anaesthetics MS-222 and clove oil on blood biochemical parameters of juvenile Siberian sturgeon (Acipenser baerii). J. Appl. Ichthyol. 2011, 27, 595-599. [CrossRef]

15. Palić, D.; Herolt, D.M.; Andreasen, C.B.; Menzel, B.W.; Roth, J.A. Anesthetic efficacy of tricaine methanesulfonate, metomidate and eugenol: Effects on plasma cortisol concentration and neutrophil function in fathead minnows (Pimephales promelas Rafinesque, 1820). Aquaculture 2006, 254, 675-685. [CrossRef]

16. Teles, M.; Oliveira, M.; Jerez-Cepa, I.; Franco-Martinez, L.; Tvarijonaviciute, A.; Tort, L.; Mancera, J.M. Transport and Recovery of Gilthead Sea Bream (Sparus aurata L.) Sedated With Clove Oil and MS222: Effects on Oxidative Stress Status. Front Physiol. 2019, 10, 523. [CrossRef]

17. Vidal, L.V.O.; Albinati, R.C.B.; Albinati, A.C.L.; de Lira, A.D.; de Almeida, T.R.; Santos, G.B. Eugenol as an anesthetic for Nile tilapia. Pesqui. Agropecu. Bras. 2008, 43, 1069-1074. [CrossRef]

18. Shukry, M.; Abd El-Kader, M.F.; Hendam, B.M.; Dawood, M.A.O.; Farrag, F.A.; Aboelenin, S.M.; Soliman, M.M.; Abdel-Latif, H.M.R. Dietary Aspergillus oryzae Modulates Serum Biochemical Indices, Immune Responses, Oxidative Stress, and Transcription of HSP70 and Cytokine Genes in Nile Tilapia Exposed to Salinity Stress. Animals 2021, 11, 1621. [CrossRef] [PubMed]

19. Tang, T.; Bai, J.; Ao, Z.; Wei, Z.; Hu, Y.; Liu, S. Effects of Dietary Paper Mulberry (Broussonetia papyrifera) on Growth Performance and Muscle Quality of Grass Carp (Ctenopharyngodon idella). Animals 2021, 11, 1655. [CrossRef]

20. Liu, W.; Shen, Y.; Li, N.; Mei, J.; Xie, J. Application of Gelatin Incorporated with Red Pitaya Peel Methanol Extract as Edible Coating for Quality Enhancement of Crayfish Procambarus clarkii during Refrigerated Storage. J. Food Qual. 2019, $2019,1-8$. [CrossRef]

21. European Food Safety Authority. Opinion of the Scientific Panel on Animal Health and Welfare (AHAW) on a request from the Commission related with the risks of poor welfare in intensive calf farming systems. EFSA J. Eur. Food Saf. Auth. $2006,4,366$.

22. Jrpeland, G.; Imsland, A.; Stien, L.H.; Bleie, H.; Roth, B.J.A.R. Effects of filleting method, stress, storage and season on the quality of farmed Atlantic cod (Gadus morhua L.). Aquac. Res. 2015, 46, 1597-1607. [CrossRef]

23. Kristoffersen, S.; Tobiassen, T.; Steinsund, V.; Olsen, R.L. Slaughter stress, postmortem muscle pH and rigor development in farmed Atlantic cod (Gadus morhua L.). Int. J. Food Sci. Technol. 2006, 41, 861-864. [CrossRef]

24. Bonga, S.E.W. The stress response in fish. Physiol. Rev. 1997, 77, 591-625. [CrossRef] [PubMed]

25. Moraes, G.; Avilez, I.M.; Altran, A.E.; Barbosa, C.C. Biochemical and hematological responses of the banded knife fish Gymnotus carapo (Linnaeus, 1758) exposed to environmental hypoxia. Braz. J. Biol. 2002, 62, 633-640. [CrossRef] [PubMed]

26. Varga, D.; Szabo, A.; Hancz, C.; Jeney, Z.; Ardo, L.; Molnar, M.; Molnar, T. Impact of Handling and Pre-Mortal Stress on the Flesh Quality of Common Carp (Cyprinus carpio L.). Isr. J. Aquacult. Bamidgeh. 2014, 66, 20746.

27. Speers-Roesch, B.; Sandblom, E.; Lau, G.Y.; Farrell, A.P.; Richards, J.G. Effects of environmental hypoxia on cardiac energy metabolism and performance in tilapia. Am. J. Physiol.-Regul. Integr. Comp. Physiol. 2010, 298, R104-R119. [CrossRef]

28. Axelrod, J.; Reisine, T.D. Stress hormones: Their interaction and regulation. Science 1984, 224, 452-459. [CrossRef]

29. Santos, E.L.R.; Rezende, F.P.; Moron, S.E. Stress-related physiological and histological responses of tambaqui (Colossoma macropomum) to transportation in water with tea tree and clove essential oil anesthetics. Aquaculture 2020, 523, 10. [CrossRef]

30. Bortoletti, M.; Maccatrozzo, L.; Radaelli, G.; Caberlotto, S.; Bertotto, D. Muscle Cortisol Levels, Expression of Glucocorticoid Receptor and Oxidative Stress Markers in the Teleost Fish Argyrosomus regius Exposed to Transport Stress. Animals 2021, 11, 1160. [CrossRef] [PubMed]

31. Nelson, K.; Jones, J.; Jacobson, S.; Reimschuessel, R. Elevated blood urea nitrogen (BUN) levels in goldfish as an indicator of gill dysfunction. J. Aquat. Anim. Health 1999, 11, 52-60. [CrossRef]

32. McCormick, S.D. Endocrine control of osmoregulation in teleost fish. Am. Zool. 2001, 41, 781-794. [CrossRef]

33. Barton, B.A.; Haukenes, A.H.; Parsons, B.G.; Reed, J.R. Plasma cortisol and chloride stress responses in juvenile walleyes during capture, transport, and stocking procedures. N. Am. J. Aqualcult. 2003, 65, 210-219. [CrossRef]

34. Gomes, L.D.; Araujo-Lima, C.; Roubach, R.; Urbinati, E.C. Assessment on the effect of salt and density on tambaqui fish transportation. Pesqui. Agropecu. Bras. 2003, 38, 283-290. [CrossRef]

35. Wu, B.; Wang, Q.; Cao, J.; Mei, J.; Xie, J. Effects of Ascorbic Acid and beta-1,3-Glucan on Survival, Physiological Response and Flesh Quality of Cultured Tiger Grouper (Epinephelus fuscoguttatus) during Simulated Transport in Water. Biology 2020, 9, 18. [CrossRef] 